\title{
STUDIES ON DESTRUCTION OF RED BLOOD CELLS. II. CHRONIC HEMOLYTIC ANEMIA WITH PAROXYSMAL NOCTURNAL HEMOGLOBINURIA: CERTAIN IMMUNOLOGICAL ASPECTS OF THE HEMOLYTIC MECHANISM \\ WITH SPECIAL REFERENCE TO SERUM COMPLEMENT ${ }^{1}$
}

\author{
By THOMAS HALE HAM AND JOHN H. DINGLE 2 \\ (From the Thorndike Memorial Laboratory, Second and Fourth Medical Services (Harvard) \\ Boston City Hospital, the Department of Medicine, and the Department of Bacteriology \\ and Immunology, Harvard Medical School, Boston)
}

(Received for publication August 1, 1939)

In previous publications $(1,2)$, certain prominent features of the mechanism of hemolysis in vitro have been described for patients with the syndrome of chronic hemolytic anemia with paroxysmal nocturnal hemoglobinuria, Marchiafava-Micheli disease $(3,4,5)$. The erythrocytes from the 5 patients studied (2) were hemolyzed by all fresh human serums of compatible blood groups, the degree of hemolysis being increased by acidification. Patients' serums, however, produced no hemolysis of normal erythrocytes. The inhibitory effect on the hemolysis of heat and certain salts known to inhibit serum complement pointed to an association of the phenomena of lysis with complement. Consequently the question was raised: was this hemolysis the result of an immunological reaction requiring complement? Augmentation of hemolytic activity by increased acidity did not rule out this possibility, since certain known antigen-antibody reactions may be enhanced by acidification $(6,7)$. Nor did the loss of activity occurring with a small amount of dilution (1:4 or $1: 5)$ militate against the hypothesis, for the system could be likened to one in which a small amount of antibody was present, thus requiring a large amount of complement for hemolysis to occur (8). This investigation was, therefore, undertaken to determine whether or not the ordinary components of an immune systemantibody, complement, and antigen-could be demonstrated.

Considering the hypothesis that a hemolytic antibody was concerned in the reaction, there

\footnotetext{
1 The investigation was aided in part by a grant from the Penrose Fund of the American Philosophical Society.

2 This work was done during the tenure of the James Jackson Cabot and DeLamar Fellowships.
}

were at least two possibilities: first, that the antibody was present in serums of both patients and normal subjects; and second, that the patient's erythrocytes were "sensitized" in vivo by a hemolytic antibody and required complement for hemolysis, as suggested by Jordan (6).

For the sake of simplicity, the data are presented in following order: (1) examination of serum for the presence of hemolytic antibody, (2) relation of complement to the mechanism of hemolysis, (3) antigenic properties of patient's and normal red blood cells, (4) examination of patient's red blood cells for hemolytic antibody, (5) comparison with human isohemolysins, (6) susceptibility of patient's erythrocytes to hemolysis in immunological systems, and (7) susceptibility to hemolysis in non-immunological systems. The case numbers correspond with those employed in the previous publication in which case reports were given (2).

\section{GENERAL METHODS}

Hemolysis of patients' red blood cells suspended in fresh serums in vitro did not necessarily occur at the natural $\mathrm{pH}$ of serum $(1,2)$ but was always observed when the acidity of serum was increased by addition of certain acids. For this reason the hemolysis test was performed with acidified serum unless otherwise noted. In these data the term "hemolytic activity" refers to the degree of hemolysis of patients' erythrocytes in such a test. The complement concentration of serum is expressed in units per cubic centimeter.

In the hemolysis test with acidified serum, described in detail previously (2), packed washed red blood cells from 0.5 cc. of a 5 per cent suspension were resuspended in plasma (heparin) or serum acidified by the addition of a 5 per cent by volume of 0.85 normal lactic acid or $1 / 3$ normal hydrochloric acid and incubated for 1 or 2 hours at $37^{\circ} \mathrm{C}$. Under these circumstances normal 
erythrocytes were never significantly hemolyzed. Venous blood defibrinated with beads was the usual source of serum and cells. As anticoagulant, heparin in a 15 per cent solution in distilled water was employed in a concentration of $130 \mathrm{mgm}$. per $100 \mathrm{cc}$. of blood. This concentration does not inhibit complement. The degree of hemolysis was estimated by inspection or by determination of the hemoglobin concentration of the supernatant serum, employing a modification of the benzidine method of Bing and Baker (9) described previously. The action of normal isohemolysins was excluded by employing, as controls, blood samples of the same or of compatible blood groups.

The complement concentration was determined by incubation for 1 hour at $37^{\circ} \mathrm{C}$. of the mixture consisting of 0.5 cc. of a 2 per cent suspension of washed sheep cells, 2 units $(0.5 \mathrm{cc}$. of a $1: 2250$ dilution) of antisheep cell rabbit serum, and $0.5 \mathrm{cc}$. of serum in graded dilutions. The highest dilution of complement giving complete hemolysis was considered as the endpoint. For the sake of numerical expression and comparison of potency, three times this dilution was considered as the number of units of complement per cubic centimeter, which must be regarded as a rough approximation due to the error in a titration of this type (10).

\section{Examination of serum for hemolytic antibody}

Fresh human serum either from the patients or from normal subjects was required for hemolysis of the patients' red blood cells. It was essential, therefore, to determine whether these serums contained a lytic substance which could be classified as a specific or non-specific antibody and which could be distinguished from the normal complement or alexin of fresh serum. The relationship of complement to the hemolytic mechanism is discussed in the next section. In the experiments reported below a series of observations was made comparing the hemolytic activity of samples of serum from Cases 1 and 3, normal infants, normal adults, and from patients whose serums contained abnormally elevated concentrations of hemolytic heterophile antibody. Finally, the serums were tested by certain absorption procedures known to remove antibodies and by methods designed to show the transfer of an antibody from serum to red blood cells (sensitization). In these procedures, however, no evidence was obtained for the presence of a hemolytic antibody in the serum of patients and of normal subjects.

a. Infants' serums. Since the serums of infants between the ages of 8 and 20 months are known to be relatively free from natural anti- bodies $(10,11,12)$, the hemolytic activity of 7 such serums was tested on the red cells from Case 3 and on cells from a normal control of the same blood group (I-AB). None of the infants were of type $I-A B$ but none of the serums showed isohemolysins for the normal type I-AB erythrocytes. However, each acidified infant's serum produced significant hemolysis of the erythrocytes of Case 3 but not of normal erythrocytes. The degree of hemolysis of patient's cells was 10 per cent or greater for 3 serums, approximately 5 per cent for 2 , and 3 per cent for 2 . Complement titers varied between 24 and 48 units.

$b$. Heterophile antibody. The hemolytic heterophile antibody for sheep cells was entirely removed from the fresh serums of Case 3 and of normal adult controls by absorptions at $0^{\circ} \mathrm{C}$. with packed washed sheep cells. Such serums when subsequently acidified maintained their hemolytic activity for the erythrocytes of Case 3 if the serum complement had not been reduced materially. . When both complement and heterophile antibody were removed by the sheep erythrocytes the serums were no longer hemolytic.

Four serums with heterophile antibody demonstrable by agglutination of sheep cells at dilutions of from 1:64 to $1: 256$ were obtained from patients convalescent from infectious mononucleosis and tested for their effect on erythrocytes from Case 3 and from a normal subject. None showed isohemolysins for group I-AB cells. The fresh acidified serum from one of the 4 patients produced no hemolysis of normal cells, however, and no more hemolysis of cells from Case 3 than was observed with a normal serum. The serums of all 4 patients produced no hemolysis of cells from Case 3 when 20 per cent by volume of whole guinea-pig serum was added as complement to the above serums which had been heated for 30 minutes at $56^{\circ} \mathrm{C}$. and then acidified. In this regard these serums were similar to normal serums as discussed in the next section.

c. Absorption tests for hemolytic antibody. In the following observations the serum from patients and normal controls was studied for the presence of hemolytic antibody by various absorption procedures. Either red blood cells or their stroma from Cases 1 and 3 or from appropriate normal subjects were utilized as potential absorbing agents. No evidence was obtained 
for the presence of a hemolytic antibody which was any more readily absorbed than was serum complement either from the patient's serum or from normal serum. There was no demonstrable difference in this respect between patients' serums and normal serums. However, as with sheep cells, when by repeated absorptions the complement concentration of either serum was materially reduced, its hemolytic activity for the patient's cells was correspondingly reduced. In these experiments the red blood cells from patients and from controls exhibited no apparent difference in absorptive activity. Normal cells and patients' cells were not sensitized nor hypersensitized, respectively, by treatment in the patient's serum (Table I). Contrary to the report of Dacie, Israels and Wilkinson (13), there was no evidence that previous chilling at $0^{\circ} \mathrm{C}$. of mixtures of patient's cells and serum increased the subsequent hemolysis at $37^{\circ} \mathrm{C}$. The methods employed in making these observations are described immediately below.

In further examinations for the presence of antibodies it should be emphasized that no cold agglutinins or isoagglutinins were ever observed at temperatures of from $0^{\circ} \mathrm{C}$. to $37^{\circ} \mathrm{C}$. for the cells and serum of patients with paroxysmal nocturnal hemoglobinuria or for normal cells of compatible blood groups suspended in their serums. Isohemolysins for the red cells of blood group II-A were encountered in the serum of Case I whose blood was of group IV-O.

\section{EXPERIMENTAL}

Absorptions with intact red blood cells were performed with samples of $3 \mathrm{cc}$. of serum from Case 3 and from a control. Each was absorbed at the natural $\mathrm{pH}$ of the serum by $1.5 \mathrm{cc}$. of washed packed erythrocytes both from Case 3 and from the control at $0^{\circ} \mathrm{C}$. for 6 and for 15 hours. The serum from each of these 4 combinations was then acidified and tested for hemolytic activity. The treated serums showed the same lytic activity as unabsorbed serums for the erythrocytes of Case 3. The procedure was then repeated as above except that the serums were adjusted to a $\mathrm{pH}$ of 6.6 by the addition of 5 per cent of $1 / 3$ normal $\mathrm{HCl}$ and the two absorptions were performed for 3 hours each; the results were the same.

In 2 observations the serum from Case 1 was $a b$ sorbed repeatedly at $37^{\circ} \mathrm{C}$. with samples of $1.0 \mathrm{cc}$. of packed red blood cells from Case 1 and from a control, respectively, employing $2.5 \mathrm{cc}$. samples of serum at its natural $\mathrm{pH}$. In the first observation with cells from Case 1, 5 successive absorptions for 30 minutes each produced moderate hemolysis during the procedure. The hemolytic activity of the acidified serums for cells from Case 1 was: before absorption, 13 per cent; after absorption with patient's cells, 7 per cent; after absorption with normal cells, 11 per cent. In the second observation, 5 absorptions of 15 minutes each were employed. The hemolytic activity of the acidified serums from Case 1 for homologous cells was: before absorption, 11 per cent; after absorption with patient's cells, 11 per cent; after absorption with normal cells, 7 per cent. These variations were not considered to be significant.

Absorptions were made with stroma prepared by the method of Thannhauser and Setz (14) from the erythrocytes of Case 3 and of a normal control. Samples of serum from Case 3 were acidified to $\mathrm{a} \mathrm{pH}$ of 6.6 by the addition of lactic acid and absorbed for 90 minutes at $37^{\circ}$ C. with 5 per cent by volume of washed packed stroma from both patient and control, respectively. These treated serums showed a slight but equal diminution of hemolytic activity for the cells of Case 3 and an equal decrease in complement titer from 48 to 12 units per cubic centimeter.

Exposure of packed red blood cells from patients to fresh homologous serum and to normal serum was carried out as follows: In one observation $0.25 \mathrm{cc}$. of cells from Case 3 were treated repeatedly at $25^{\circ} \mathrm{C}$. for 10 minutes with samples of $1.0 \mathrm{cc}$. of fresh serum from Case 3 at its natural $\mathrm{pH}$. The hemolysis of these cells when suspended in fresh samples of acidified serum was: untreated cells, 11 per cent; cells treated once with fresh serum, 10 per cent; cells treated 6 times with fresh serum, 8 per cent. There was no evidence, therefore, of hypersensitization of patient's erythrocytes. In another ex-

TABLE I

Patient's erythrocytes not hypersensitized by own serum *

\begin{tabular}{c|c|c|c|c}
\hline \hline \multicolumn{2}{c|}{ Serum mixturet } & \multicolumn{2}{|c}{$\begin{array}{c}\text { Hemolysis of red blood cells from Case } 3 \\
\text { after treatment with serum or saline }\end{array}$} \\
Active serum & $\begin{array}{c}\text { Serum } \\
\text { heated at } \\
56^{\circ} \text { C. for } \\
5 \text { minutes }\end{array}$ & $\begin{array}{c}\text { Heated } \\
\text { serum from } \\
\text { Case } 3\end{array}$ & $\begin{array}{c}\text { Heated } \\
\text { serum from } \\
\text { normal } \\
\text { subject }\end{array}$ & Saline \\
\cline { 2 - 5 } per cent & per cent & per cent & per cent & per cent \\
100 & & 9.0 & 10.0 & 12.0 \\
80 & 20 & 4.0 & 4.0 & 6.0 \\
50 & 50 & 0.3 & 0.1 & 1.5 \\
40 & 60 & 0 & 0 & 1.0 \\
30 & 70 & 0 & 0 & 0 \\
Saline & 0 & 0 & 0 & 0 \\
\hline
\end{tabular}

* Washed packed erythrocytes from Case 3 were made to a 5 per cent suspension in serum (heated $56^{\circ} \mathrm{C}$. for 5 minutes) from Case 3 , from a normal subject, and in saline. Mixtures were incubated 1 hour at $37^{\circ} \mathrm{C}$., chilled 15 hours, the supernatant removed, and hemolysis of treated cells tested with mixtures of active and inactive serum from Case 3.

$+1 / 3$ Normal hydrochloric acid added, 5 per cent by volume, saline not acidified. 
periment 5 per cent suspensions of washed red cells from Case 3 were made in heated serums $\left(56^{\circ}\right.$ C. for 5 minutes) from Case 3 and from a normal subject, and in salt solution, respectively. The suspensions were incubated at $37^{\circ} \mathrm{C}$. for 1 hour and stored overnight at $5^{\circ} \mathrm{C}$. After removal of the supernatant fluids the treated cells were resuspended in varying mixtures of heated and fresh acidified serum from Case 3 in the proportions shown in Table I. There was no evidence of increased sensitization of cells to hemolysis by previous exposure to the serum of Case 3 .

\section{Relation of complement to the mechanism of hemolysis}

No evidence was obtained from the above observations that a hemolytic antibody was present in the serums examined. A serum factor was essential for hemolysis, however, and had many characteristics similar to those of serum complement as mentioned above. A prominent exception, however, to these resemblances between the serum factor and complement is the previously reported $(1,2,13,15)$ failure of fresh guinea-pig serum to restore the hemolytic activity of human serum heated at $56^{\circ} \mathrm{C}$. for 30 minutes. This problem is further investigated below, especially because Dingle, Fothergill and Chandler (10) have shown that certain immunological reactions require human complement and are not activated by animal serums. Accordingly, in order to compare further the behavior of the serum factor and of complement, the serums from 5 patients and from normal subjects were treated by procedures known to increase, decrease, or inhibit the action of complement as a whole or of one or more of the components of complement (7). Serums treated in this manner were then examined for their hemolytic activity for patients' red cells and for their concentration of complement.

a. Increase of complement concentration. The concentration of complement in human serum was increased by two procedures; first, the addition of guinea-pig serum, and second, the desiccation of human serum by lyophilization (16) and resolution of the dried material in one-half the original volume. The alkaline $\mathrm{pH}$ of lyophilized serum was adjusted by the addition of lactic acid and tested, as was the original serum, over a range of $\mathrm{pH}$ of from 6 to 8 (2).

In 13 of 15 observations the addition of 20 per cent by volume of fresh undiluted guinea-pig serum to active human serum from adults produced a significant increase in complement titer, when compared to the original human serum, and a significant increase in hemolysis of the patient's erythrocytes but no hemolysis of normal erythrocytes. These results are in agreement with those of Dacie, Israels and Wilkinson (13). In 2 instances there was no increase in hemolysis of patient's cells. With infant's serum the results of the same procedure were not uniform. Although the complement titer was increased in all instances, a definite increase in hemolytic activity was observed in only 2 instances, a slight increase in 2 , no change in 1 , and hemolytic activity was entirely eliminated in 2 instances. There was no apparent explanation for the latter observation.

Lyophilized serum redissolved in its original volume contained the same apparent complement concentration as the original serum but its hemolytic activity was always decreased significantly. Lyophilized serum, which was redissolved in onehalf its original volume and which contained twice the original complement concentration, produced either no hemolysis of patient's erythrocytes or only slight hemolysis. Thus lyophilization apparently decreased the lytic activity of human serum for patient's cells without demonstrable alteration of complement content.

b. Decrease of complement concentration. As already stated in section 1 , when human serum was treated with sheep or human red cells or with the stroma of human red cells, the serum was rendered non-hemolytic for patient's erythrocytes in those instances in which complement was significantly reduced. In the following observations a direct study of the effect of decreasing the complement concentration was undertaken. The reactive components of complement were removed in part or completely from human serum by each of 3 procedures: absorption with sensitized or unsensitized influenza bacilli; standing at room temperature; or by filtration through Berkefeld or Seitz filters (17). The hemolytic activity of the treated serums was then tested on patient's erythrocytes and compared with the activity of an unmanipulated sample. In general there was a direct correlation between the complement concentration and hemolytic activity. 


\section{EXPERIMENTAL}

Absorption by sensitized or unsensitized influenza bacilli of serums from Case 3 and a normal subject decreased or removed complement, and correspondingly affected the hemolytic power of the treated serums. Hemophilus influenzae was grown on 12 agar plates and a heavy suspension made in $40 \mathrm{cc}$. of saline. To sensitize the organisms, equal volumes of suspension ${ }^{3}$ and anti-influenza rabbit serum diluted $1: 40$ were mixed and incubated 30 minutes at $37^{\circ} \mathrm{C}$. The immune rabbit serum was prepared as described by Dingle, Fothergill and Chandler (10). For absorption of human serum, measured quantities of suspension were packed by centrifugation, the supernatant fluid discarded, and the organisms resuspended in serum. After incubation for 1 hour at $37^{\circ} \mathrm{C}$. the serum was removed and acidified.

Standing at room temperature is well known to decrease the concentration of serum complement. Accordingly, 2 normal serums and the serum of Case 3 were allowed to stand under sterile conditions at $25^{\circ} \mathrm{C}$. for 5 days. By this means a reduction of complement from 48 units per cc. of serum to a trace was obtained. The hemolytic activity was absent from 2 and greatly reduced in the third serum. The addition of 20 per cent by volume of fresh undiluted guinea-pig serum to the stored serums made no significant change in hemolytic activity but partially restored the complement concentrations to 24 units per cubic centimeter.

Repeated filtration through clean Berkefeld candles has been demonstrated by Strong and Culbertson (17) to remove all the known components of complement from fresh human serum. The thermolabile elements were the first to be removed and were not demonstrable in serum after from 3 to 6 filtrations. The heat-stable third and fourth components could still be detected after 9 filtrations.

In the present experiments, after one Berkefeld filtration of the 4 serums tested, there was no measurable decrease in complement concentration, but the hemolytic activity was materially reduced in 2 instances and eliminated in 2 instances. The addition of 20 per cent by volume of fresh undiluted guinea-pig serum restored the hemolytic activity completely in 1 instance, partially in 2 instances and failed to restore it in 1 instance.

After 5 passages through Seitz filters there was no detectable complement or hemolytic activity. The hemolytic activity, however, was not restored by the addition of 20 per cent by volume of fresh undiluted guinea-pig serum.

c. Inhibition of complement. As reported in previous communications $(1,2)$, certain acids and salts (sodium citrate, citric acid, potassium oxalate and potassium cyanide) completely inhibited the lysis of the patients' red cells in the usual hemolysis test with acidified serum or plasma. Partial

8 These suspensions were prepared through the courtesy of Dr. L. R. Seidman. inhibition was observed with oxalic and phosphoric acids and with heparin in concentrations greater than $130 \mathrm{mgm}$. per $100 \mathrm{cc}$. of blood. Jordan (6) reported similar results in this disease with the above anticoagulants as well as with fluoride, hirudin and liquoid (Roche). Other investigators $(18,19,20)$ have shown that the acids and salts referred to above inhibit complement action. There was a definite parallelism, therefore, between the inhibitory action of these agents both on complement and on hemolytic activity.

d. Removal or inactivation of fractions or components of complement. Complement can be separated by the proper procedures into globulin and albumin fractions and third and fourth components $(21,22,23)$. The globulin fraction or midpiece and the albumin fraction or endpiece both contain thermolabile elements (7). These two fractions, however, contain the essential components of complement since their combination restores the full activity of complement. The third component can be removed by yeast or zy$\min (17,22)$, or can be inactivated by cobra venom $(24,25)$. The fourth component can be inactivated by ammonium hydroxide or ammonium salts (23). The third and fourth components are relatively heat stable. Serums treated by such procedures have no apparent complement activity when used alone and recombination of these fractions restores complement action only when such mixtures contain qualitatively the above constituents, each in active condition. Accordingly, serums from patients and controls were treated by procedures described below, in order to separate, remove or inactivate these individual components of complement. Thereafter, the complement titer and hemolytic activity of the serums were determined before and after the addition of serum from the guinea-pig and from certain other ainmals.

The globulin and albumin fractions, after separation, showed neither complement nor hemolytic activity when employed alone but both qualities were restored by recombination of the fractions.

\section{EXPERIMENTAL}

The albumin and globulin fractions of human serum were separated as described by Liefmann (21). The 
serum, diluted 1:10 with distilled water, was saturated with carbon dioxide at room temperature for 10 minutes and the precipitated globulin removed by centrifugation, washed 3 times with distilled water and dissolved in the same volume of saline as the original serum. The supernatant solution containing the albumin fraction was dried by lyophilization and redissolved in the same volume of distilled water as the original serum. When both fractions were recombined the precipitated globulin was dissolved in the albumin fraction, thus restoring the mixture to the same concentration of these constituents and of salts as existed in the original serum.

The thermolabile components of complement were inactivated in the following observations by exposure of human serum to varying temperatures. The hemolytic activity of serum disappeared before complement was measurably decreased in concentration or when only moderately decreased. Heated human serum, showing no lytic activity but definite complement activity, always showed partial restoration of lytic activity on the addition of fresh guinea-pig serum. When human complement was completely inactivated by heat, the hemolytic activity was eliminated. It was not restored either by small amounts of fresh human serum or by the fresh serums of certain animals including the guinea-pig. The data from representative observations are shown in Tables II, III, IV and V, and the procedures are described briefly below.

TABLE II

Effect of heating serum for 7 minutes at $40-60^{\circ} \mathrm{C} .^{*}$

\begin{tabular}{c|c|c|c|c}
\hline $\begin{array}{c}\text { Temperatures } \\
\text { of serumf } \\
\text { heated for } \\
7 \text { minutes }\end{array}$ & $\begin{array}{c}\text { Source of } \\
\text { serum } \\
\text { Patient (P) } \\
\text { Control (C) }\end{array}$ & $\begin{array}{c}\text { Hemolysis } \\
\text { of red blood } \\
\text { cells from } \\
\text { Case 3 }\end{array}$ & $\begin{array}{c}\text { Hemolysis } \\
\text { of normal } \\
\text { red blood } \\
\text { cells }\end{array}$ & $\begin{array}{c}\text { Concentra- } \\
\text { tion of } \\
\text { complement }\end{array}$ \\
\hline $\begin{array}{c}\text { degrees } \\
\text { centigrade }\end{array}$ & & per cent & per cent & units per cc. \\
Unheated & $\mathrm{P}$ & 16 & 0 & 48 \\
40 & $\mathrm{C}$ & 17 & 0 & 48 \\
& $\mathrm{P}$ & 16 & 0 & 48 \\
45 & $\mathrm{C}$ & 15 & 0 & 48 \\
50 & $\mathrm{P}$ & 13 & 0 & 48 \\
& $\mathrm{C}$ & 10 & 0 & 48 \\
55 & $\mathrm{P}$ & 0 & 0 & 12 \\
60 & $\mathrm{C}$ & 0 & 0 & 12 \\
& $\mathrm{P}$ & 0 & 0 & 0 \\
& $\mathrm{C}$ & 0 & 0 & 0 \\
& $\mathrm{P}$ & 0 & 0 & 0 \\
& $\mathrm{C}$ & 0 & 0 & 0 \\
\hline
\end{tabular}

* Hemolytic activity of human serum disappears before complement at $50^{\circ} \mathrm{C}$.

† After heating: lactic acid added, 5 per cent by volume, 20 millimolar concentration.
TABLE III

Effect of adding fresh human serum and guinea-pig serum to heated serum*

\begin{tabular}{|c|c|c|c|c|c|c|}
\hline $\begin{array}{l}\text { Source of } \\
\text { serum } \\
\text { Patient } \\
\text { (P) } \\
\text { Control } \\
\text { (C) }\end{array}$ & $\begin{array}{c}\text { Fresh } \\
\text { human } \\
\text { serum } \dagger\end{array}$ & $\begin{array}{c}\text { Human } \\
\text { gerumf } \\
\text { heated } \\
\text { at } 50^{\circ} \mathrm{C} . \\
\text { for } 7 \\
\text { minutes }\end{array}$ & $\begin{array}{l}\text { Fresh } \\
\text { undi- } \\
\text { luted } \\
\text { guinea- } \\
\text { pig } \\
\text { serum }\end{array}$ & $\begin{array}{l}\text { Hemolysis } \\
\text { of red } \\
\text { blood cells } \\
\text { from } \\
\text { Case } 3\end{array}$ & $\begin{array}{c}\text { Hemol- } \\
\text { ysis of } \\
\text { normal } \\
\text { red } \\
\text { blood } \\
\text { cells }\end{array}$ & $\begin{array}{c}\text { Concen- } \\
\text { tration } \\
\text { of } \\
\text { comple- } \\
\text { ment }\end{array}$ \\
\hline & $\begin{array}{l}\text { per cent } \\
\text { of } \\
\text { mixture }\end{array}$ & $\begin{array}{l}\text { per cent } \\
\text { of } \\
\text { mixture }\end{array}$ & $\begin{array}{l}\text { per cent } \\
\text { of } \\
\text { mixture }\end{array}$ & & per cent & $\begin{array}{c}\text { units } \\
\text { per cc. }\end{array}$ \\
\hline $\begin{array}{l}\mathbf{P} \\
C \\
\mathbf{P} \\
\mathbf{C} \\
\mathbf{P} \\
\mathrm{C} \\
\mathbf{P} \\
\mathrm{C}\end{array}$ & $\begin{array}{l}100 \\
100\end{array}$ & $\begin{array}{r}100 \\
100 \\
80 \\
80 \\
90 \\
90\end{array}$ & $\begin{array}{l}10 \\
10\end{array}$ & $\begin{array}{r}16 \\
13 \\
0 \\
0 \\
0 \\
0 \\
0 \\
8 \\
9\end{array}$ & $\begin{array}{l} \pm \\
0 \\
0 \\
0 \\
0 \\
0 \\
0 \\
0\end{array}$ & $\begin{array}{l}24 \\
24 \\
24 \\
24 \\
12 \\
24 \\
48 \\
48\end{array}$ \\
\hline
\end{tabular}

* Hemolytic activity was restored by guinea-pig serum and not by 20 per cent by volume of fresh human serum when added to human serum partially inactivated by heat.

$\dagger$ Lactic acid added, 5 per cent by volume, 20 millimolar concentration.

$\ddagger$ Acid added after heating.

TABLE IV

Effect of adding guinea-pig serum to human serum heated at $56^{\circ} \mathrm{C}$ *

\begin{tabular}{|c|c|c|c|c|c|c|c|}
\hline $\begin{array}{c}\text { Source } \\
\text { of gerum } \\
\text { Patient } \\
\text { (P) } \\
\text { Control } \\
\text { (C) }\end{array}$ & $\begin{array}{c}\text { Fresh } \\
\text { human } \\
\text { serum } \neq\end{array}$ & $\begin{array}{l}\text { Length } \\
\text { of time } \\
\text { human } \\
\text { gerum } \\
\text { heated } \\
\text { at } \\
56^{\circ} \mathrm{C} \text {. }\end{array}$ & $\begin{array}{c}\text { Heated } \\
\text { human } \\
\text { serum } \ddagger\end{array}$ & $\begin{array}{l}\text { Fresh } \\
\text { undi- } \\
\text { luted } \\
\text { guinea- } \\
\text { pig } \\
\text { serum } \ddagger\end{array}$ & $\begin{array}{l}\text { Hemol- } \\
\text { ysis of } \\
\text { red } \\
\text { blood } \\
\text { cells } \\
\text { from } \\
\text { Case } 3\end{array}$ & $\begin{array}{c}\text { Hemol- } \\
\text { ysis of } \\
\text { normal } \\
\text { red } \\
\text { blood } \\
\text { cells }\end{array}$ & $\begin{array}{c}\text { Concen- } \\
\text { tration } \\
\text { of } \\
\text { comple- } \\
\text { ment }\end{array}$ \\
\hline $\mathbf{P}$ & $\begin{array}{c}\text { per } \\
\text { cent of } \\
\text { mixture } \\
100 \\
80\end{array}$ & $\begin{array}{c}\text { minutes } \\
0 \\
0\end{array}$ & $\begin{array}{c}\text { per } \\
\text { cent of } \\
\text { mixture }\end{array}$ & $\begin{array}{c}\begin{array}{c}\text { per } \\
\text { cent of } \\
\text { mixture }\end{array} \\
20\end{array}$ & $\begin{array}{c}\text { per cent } \\
17 \\
19\end{array}$ & $\begin{array}{c}\text { per cent } \\
0 \\
0\end{array}$ & $\begin{array}{c}\text { units } \\
\text { per cc. } \\
12 \\
24\end{array}$ \\
\hline C & $\begin{array}{r}100 \\
80\end{array}$ & $\begin{array}{l}0 \\
0\end{array}$ & & 20 & $\begin{array}{l}13 \\
20\end{array}$ & $\begin{array}{l}0 \\
0\end{array}$ & $\begin{array}{l}24 \\
24\end{array}$ \\
\hline $\mathbf{P}$ & & & $\begin{array}{r}100 \\
80\end{array}$ & 20 & $\begin{array}{l}0 \\
2\end{array}$ & $\begin{array}{l}0 \\
0\end{array}$ & $\begin{array}{r}6 \\
24\end{array}$ \\
\hline C & & & $\begin{array}{r}100 \\
80\end{array}$ & 20 & $\begin{array}{r}0 \\
10\end{array}$ & $\begin{array}{l}0 \\
0\end{array}$ & $\begin{array}{r}6 \\
24\end{array}$ \\
\hline $\mathbf{P}$ & & \multirow{2}{*}{5} & $\begin{array}{r}100 \\
80\end{array}$ & 20 & $\begin{array}{l}0 \\
0\end{array}$ & $\begin{array}{l}0 \\
0\end{array}$ & $\begin{array}{r}0 \\
12\end{array}$ \\
\hline C & & & $\begin{array}{r}100 \\
80\end{array}$ & 20 & $\begin{array}{l}0 \\
0\end{array}$ & $\begin{array}{l}\mathbf{0} \\
\mathbf{0}\end{array}$ & $\begin{array}{r}0 \\
24\end{array}$ \\
\hline $\mathbf{P}$ & & \multirow{2}{*}{$10 \dagger$} & $\begin{array}{r}100 \\
80\end{array}$ & 20 & $\begin{array}{l}0 \\
0\end{array}$ & $\begin{array}{l}\mathbf{0} \\
\mathbf{0}\end{array}$ & $\begin{array}{r}0 \\
24\end{array}$ \\
\hline C & & & $\begin{array}{r}100 \\
80\end{array}$ & 20 & $\begin{array}{l}0 \\
0\end{array}$ & $\begin{array}{l}0 \\
0\end{array}$ & $\begin{array}{r}0 \\
24\end{array}$ \\
\hline
\end{tabular}

* Hemolytic activity was restored by guinea-pig serum when human complement was only partially inactivated

+ Serum heated for intervals of 15,20 and 30 minutes gave results identical with those heated for 5 and 10 minutes.

$\ddagger$ Lactic acid added (after heating), 5 per cent by volume, 20 millimolar concentration. 
TABLE V

Comparison of human and guinea-pig complement *

\begin{tabular}{|c|c|c|c|c|c|c|}
\hline $\begin{array}{l}\text { Source of } \\
\text { serum }\end{array}$ & $\begin{array}{c}\text { Fresh } \\
\text { human } \\
\text { serumf }\end{array}$ & $\begin{array}{c}\text { Human } \\
\text { serumf } \\
\text { heated } \\
\text { at } 56^{\circ} \mathrm{C} . \\
\text { for } 5 . \\
\text { minutes }\end{array}$ & $\begin{array}{l}\text { Fresh } \\
\text { undi- } \\
\text { luted } \\
\text { guinea- } \\
\text { pig } \\
\text { serum }\end{array}$ & $\begin{array}{c}\text { Hemolysist } \\
\text { of red } \\
\text { blood cells } \\
\text { from } \\
\text { Case } 3\end{array}$ & $\begin{array}{c}\text { Hemol- } \\
\text { ysis of } \\
\text { normal } \\
\text { red } \\
\text { blood } \\
\text { cells }\end{array}$ & $\begin{array}{c}\text { Concen- } \\
\text { tration } \\
\text { of } \\
\text { comple- } \\
\text { ment }\end{array}$ \\
\hline Patient & $\begin{array}{c}\text { per cent } \\
\text { of } \\
\text { mixture } \\
100 \\
50 \\
20\end{array}$ & $\begin{array}{c}\text { per cent } \\
\text { of } \\
\text { mixture } \\
100 \\
50 \\
80 \\
80\end{array}$ & $\begin{array}{l}\text { per cent } \\
\text { of } \\
\text { mixture }\end{array}$ & $\begin{array}{c}\text { per cent } \\
+++ \\
0 \\
\text { trace } \\
0 \\
0\end{array}$ & $\begin{array}{c}\text { per cent } \\
0 \\
0 \\
0 \\
0 \\
0\end{array}$ & $\begin{array}{c}\text { units } \\
\text { per cc. } \\
24 \\
0 \\
24 \\
3 \\
48\end{array}$ \\
\hline Control & $\begin{array}{r}100 \\
50 \\
30 \\
20\end{array}$ & $\begin{array}{r}100 \\
50 \\
70 \\
80 \\
80\end{array}$ & 20 & $\begin{array}{r}30 \\
0 \\
19 \\
10 \\
8 \\
0\end{array}$ & $\begin{array}{c}\text { trace } \\
0 \\
\pm \\
0 \\
0 \\
0\end{array}$ & $\begin{array}{r}48 \\
0 \\
24 \\
12 \\
6 \\
48\end{array}$ \\
\hline
\end{tabular}

* Effect of adding human serum and guinea-pig serum to heat-inactivated human serum.

$\uparrow$ Approximate hemolysis:

+10 per cent

++20 per cent

+++30 per cent.

‡ Lactic acid added (after heating), 5 per cent by volume, 20 millimolar concentration.

\section{EXPERIMENTAL}

Human serum was heated for 7 minutes at various temperatures between $40^{\circ} \mathrm{C}$. and $60^{\circ} \mathrm{C}$. The results are shown in Table II. At $40^{\circ} \mathrm{C}$. and $45^{\circ} \mathrm{C}$. no significant loss of complement or hemolytic power occurred. At $50^{\circ} \mathrm{C}$. complement was only moderately decreased in concentration but hemolytic activity was completely eliminated. At $55^{\circ} \mathrm{C}$. and $60^{\circ} \mathrm{C}$. both qualities were destroyed. As shown in Table III, serum heated at $50^{\circ} \mathrm{C}$. for 7 minutes was not hemolytic when used alone and the lytic power was not restored by the addition of 20 per cent by volume of fresh human serum. Guineapig serum, however, added to such heated serum in a concentration of 10 per cent by volume of undiluted fresh serum increased the complement titer and restored in part the hemolytic activity.

Human serum was heated at $56^{\circ} \mathrm{C}$. for various periods of time from 1 to 30 minutes. The results are shown in Table IV. Serum so heated for 1 minute showed diminished complement concentration and no hemolytic power. The addition of guinea-pig serum as employed above restored completely the complement titer and also restored in part the hemolytic power. After heating for from 5 to 30 minutes, however, both complement and hemolytic activity were absent. Although the complement titer was restored by adding guinea-pig serum, the hemolytic activity was not restored to these mixtures.

Human serum and certain animal serums were further investigated as sources of the thermolabile components of complement. Mixtures of fresh human serum (20 to 50 per cent) and heat-inactivated human serum showed hemolytic activity which varied roughly as the complement titer, as evident from the data in Table $V$ (see also Table I).

Guinea-pig serum was investigated for its effect in concentrations up to 50 per cent by volume of fresh undiluted serum added to heated human serum. Guineapig serum in dilutions of from $1: 5$ to $1: 40$ was added to an equal volume of a 5 per cent suspension of patient's and of normal cells, respectively. For these experiments whole guinea-pig serum was first absorbed with an equal volume of washed packed human erythrocytes for from 30 to 90 minutes at $0^{\circ} \mathrm{C}$. in order to reduce the concentration of hemolysins of guinea-pig serum for human cells. In these observations, such absorbed serum showed full complement activity but did not restore hemolytic activity to heated human serum, nor produce hemolysis when employed alone in the above dilutions. The same results were obtained in identical experiments employing unabsorbed serums from rabbit, dog, sheep and steer. When high concentrations of these unabsorbed animal serums were employed, hemolysis was observed in similar amounts for patient's cells and for normal cells of all 4 blood groups.

The third component of complement was removed from serum by zymin made from yeast. There was a direct correlation between the removal of hemolytic activity and of complement depending upon the volume of zymin and the time employed for absorption. Hemolytic activity always disappeared before complement was entirely removed. Combination of equal quantities of zymin-treated and of heat-inactivated human serums showed only slight return of complement activity and no return of lytic power. It was impossible by the methods employed to restore a high concentration of complement in such mixtures. However, whole untreated guinea-pig serum did restore a high complement concentration to zymin-inactivated human serum and in 2 of 4 observations restored in part the hemolytic activity to the zymin-treated human serum.

\section{EXPERIMENTAL}

Serums from patients and controls were treated with measured amounts of zymin prepared from baker's yeast by the Strong and Culbertson (17) modification of the method of Whitehead, Gordon and Wormall (22). Zymin suspensions were centrifuged and the supernatant fluid was discarded. The packed zymin was then resuspended in the serums in concentrations of from 0.5 to 6 per cent by volume and the mixture incubated at $37^{\circ} \mathrm{C}$. for from 15 to 30 minutes.

The fourth component of complement was inactivated by the use of ammonium hydroxide. 
As shown in the data of Table VI, there was direct correlation between the removal of hemolytic activity and of complement; partially inactivated serum retained hemolytic potency roughly proportional to the complement concentration; completely inactivated serum showed no hemolytic activity. The combination of samples of human serum, inactivated respectively by ammonium hydroxide and by heat (presumably representing qualitatively all components of complement) restored the complement concentration to about one-fourth of its original titer; and for 1 of the 3 serums tested such recombination also restored in part the hemolytic activity. As shown in Table VII, the mixture containing the highest concentration of ammonium hydroxide-treated serum showed the greatest hemolytic power and complement concentration.

The addition of fresh guinea-pig serum always restored the hemolytic activity to human serum inactivated by ammonium hydroxide. Therefore, guinea-pig serum apparently supplied the fourth component of human serum essential for hemolysis but, as shown above, never supplied the ther-

TABLE VI

Effect of ammonium hydroxide on complement and hemolytic activity *

\begin{tabular}{|c|c|c|c|c|c|}
\hline \multicolumn{2}{|c|}{$\begin{array}{c}\text { Serum-ammonium } \\
\text { hydroxide mixtures } \\
\text { incubated } 1 \text { hour } \\
\text { at } 37^{\circ} \mathrm{C} .7\end{array}$} & \multirow{2}{*}{$\begin{array}{l}\text { Fresh human } \\
\text { serum } \ddagger\end{array}$} & \multirow{2}{*}{$\begin{array}{l}\text { Hemolysist } \\
\text { of red } \\
\text { blood cells } \\
\text { from Case } 3\end{array}$} & \multirow{2}{*}{$\begin{array}{c}\text { Hemol- } \\
\text { ysis of } \\
\text { normal } \\
\text { red } \\
\text { blood } \\
\text { cells }\end{array}$} & \multirow{2}{*}{$\begin{array}{l}\text { Concen- } \\
\text { tration } \\
\text { of } \\
\text { comple- } \\
\text { ment }\end{array}$} \\
\hline $\begin{array}{l}\text { Volume } \\
\text { t normal } \\
\text { ammo- } \\
\text { nium hy- } \\
\text { droxide }\end{array}$ & $\begin{array}{l}\text { Volume } \\
\text { serum }\end{array}$ & & & & \\
\hline$c c$. & cc. & $\begin{array}{c}\text { Per cent of } \\
\text { mixture } \\
100 \\
100 \\
\text { Incubated } \\
1 \text { hour at }\end{array}$ & ++ & 0 & $\begin{array}{c}\text { units } \\
\text { per cc. } \\
48\end{array}$ \\
\hline $\begin{array}{l}0.375 \\
0.250 \\
0.187 \\
0.125 \\
0.075\end{array}$ & $\begin{array}{l}1.65 \\
1.87 \\
2.00 \\
2.10 \\
2.20\end{array}$ & & $\begin{array}{c}0 \\
0 \\
0 \\
\text { trace } \\
+\end{array}$ & $\begin{array}{l}0 \\
0 \\
0 \\
0 \\
0\end{array}$ & $\begin{array}{r}20 \\
0 \\
0 \\
0 \\
3 \\
24\end{array}$ \\
\hline
\end{tabular}

* Serum from normal subject treated with increasing amounts of ammonium hydroxide.

† Approximate hemolysis:

+10 per cent

++20 per cent

+++30 per cent.

$\ddagger$ Serum pH finally adjusted to approximately 6.5 by adding hydrochloric acid.
TABLE VII

Mixture of inactivated serums restore hemolytic activity and complement *

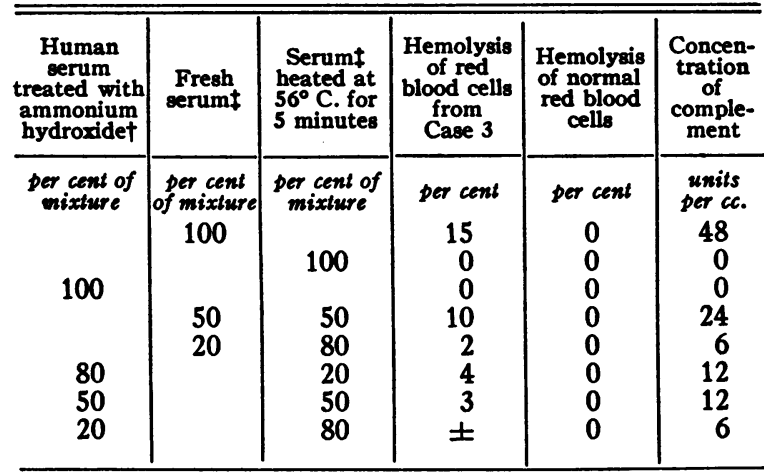

* Serum from normal subject inactivated by ammonium hydroxide and by heat on recombination shows both hemolytic activity and complement.

† See experimental.

† Serum $\mathrm{pH}$ finally adjusted to approximately 6.5 by adding hydrochloric acid.

molabile components of heated human serum. The hemolytic activity was restored in part to ammonium hydroxide-inactivated human serum by whole guinea-pig serum and by heated guineapig serum but not by guinea-pig serum inactivated by ammonium hydroxide.

The combination of equal amounts of samples of serum treated with zymin and with ammonium hydroxide, respectively, restored approximately one-half of the complement concentration of the original serum, but did not restore the hemolytic power. Similar results, as referred to above, were obtained with mixtures of equal amounts of fresh and of heat-inactivated serum. Therefore, failure to observe hemolysis with either of these 2 different mixtures may have been due to a decreased quantity of complement and not to the lack of a particular component of complement.

\section{EXPERIMENTAL}

The procedure of inactivation of human serum by alkalinization to $\mathrm{pH} 9.0$ or 9.1 with ammonium hydroxide, and the subsequent readjustment of the $\mathrm{pH}$ of the serum to approximately 6.5 , were somewhat modified from the method of Gordon et al (23), in order to decrease the dilution of serum by the reagents. A mixture of 0.075 cc. of $1 / 8$ normal ammonium hydroxide and 0.884 cc. of serum was incubated at $37^{\circ} \mathrm{C}$. for 75 minutes. The $\mathrm{pH}$ was then adjusted immediately to approximately 6.5 by the addition of $0.041 \mathrm{cc}$. of 1.0 normal hydrochloric acid and the hemolytic activity tested as usual. In 1 observation, using sodium hydroxide instead of ammonium 
hydroxide to produce a serum $\mathrm{pH}$ of 9.0 to 9.1 , the complement was similarly inactivated and was restored in part by the addition of an equal volume of serum inactivated by heat $\left(56^{\circ} \mathrm{C}\right.$. for 5 minutes $)$. The serum treated with sodium hydroxide had no hemolytic activity for patient's cells.

$e$. Influence of the hemolytic reaction on complement concentration. From the above observations it was evident that complement or a complement-like substance was closely related to the hemolytic activity of serum. It was important, therefore, to investigate whether complement was fixed or utilized during the hemolytic reaction. When samples of acidified serum from Case 3 or from a normal subject were treated repeatedly with packed washed red blood cells from either subject, hemolysis of patient's cells occurred in decreasing amounts with each exposure to fresh cells. There was, as usual, no significant hemolysis of normal cells. After 4 such exposures, the complement concentrations of both the patient's and the normal serums were decreased to one-half the original quantity and the serums were materially diminished in hemolytic activity for patient's cells. No evidence was obtained, therefore, for specific complement fixation or utilization by the process of hemolysis of patient's cells, since normal human cells (without hemolyzing) removed complement at the same rate.

\section{Antigenic properties of patient's and of normal red blood cells}

The red blood cells of patients with paroxysmal nocturnal hemoglobinuria, in contrast to those of normal subjects, have been demonstrated to be abnormally subject to hemolysis in acidified human serum containing complement. It was thus possible that the patient's cells had an antigenic structure differing from normal cells. No significant difference was observed, however, between the antigenic properties of red blood cells from Case 3 and from a normal subject of the same blood group when immune rabbit serums were produced against these erythrocytes and the antibody concentrations compared in cross-absorption experiments.

\section{EXPERIMENTAL}

Red blood cells from Case 3 and from a normal subject of the same blood group (I-AB) were obtained from defibrinated blood, washed 3 times and made to 33 per cent suspensions in saline. Three albino rabbits were immunized with each suspension. Each animal received daily intravenous injections of 1,2 and then $6 \mathrm{cc}$. of suspension for a total of 6 injections, followed in 10 days by a similar series of 6 daily injections. Eight days after the last injection, the antiserums were tested for hemolysins and agglutinins with red blood cells from each subject before and after cross-absorptions of each antiserum by the erythrocytes of the patient and control, respectively. For each absorption the rabbit antiserums, inactivated at $56^{\circ} \mathrm{C}$. for from 30 to 60 minutes, and diluted 1 to 5 , were treated with from 25 to 33 per cent by volume of washed packed erythrocytes for 30 minutes at $37^{\circ} \mathrm{C}$.

All of the rabbit-immune serums showed agglutination in high dilutions, varying from $1: 2500$ to $1: 5000$. Agglutination appeared in approximately equal dilutions with the washed red blood cells either from the patient or from the control. Cross-absorptions of each serum by the erythrocytes of the patient and of the control, respectively, removed the agglutinins for the red cells of both subjects at the same rate and to the same extent. The unabsorbed rabbit antiserums produced complete hemolysis at the relatively low maximum dilution of $1: 100$. As in the agglutination tests, each rabbit antiserum possessed equal hemolytic activity for the erythrocytes of both subjects; and cross-absorptions showed no selective removal of hemolysin by red cells of either subject.

\section{Examination of patient's red blood cells for hemolytic antibody}

Although no antigenic differences between patient's and normal erythrocytes were demonstrable in the above experiments, there remained the distinct possibility that the abnormal cells contained a hemolytic substance or antibody. It was conceivable, as one hypothesis, that the patient had developed a specific hemolytic antibody for his own red blood cells (as antigen), thus producing autoimmunization. In this event, a small amount of hemolytic antibody in the plasma might be completely absorbed by the antigen (red cells) leaving no demonstrable free antibody. Such "sensitized" cells might then hemolyze only in the presence of human complement. Should the amount of available antibody vary in concentration, it is evident that the degree of "sensitization" or susceptibility to hemolysis of patient's red blood cells would be variable in vivo, and might be observed to vary in a similar fashion in vitro under standardized experimental conditions. Accordingly, the red blood cells from pa- 
tients were examined, first, for differences in susceptibility to hemolysis, and, second, for the presence of hemolytic antibody which might be separated from the erythrocyte by procedures known to dissociate antigen-antibody combinations.

Comparisons of the susceptibility to hemolysis in vitro and in vivo of red blood cells from 4 patients showed striking correlation in individual patients between the susceptibility to hemolysis in vitro and the apparent degree of intravascular hemolysis as estimated by clinical criteria. This correlation reported previously (2) held for widely differing rates of blood destruction in different patients. Moreover, in the present prolonged study of Case 3 , it was observed that such susceptibility in vitro varied materially at different periods in the same patient and corresponded with the apparent amount of hemolysis in vivo. This was demonstrated by determining at different times the percentage of hemolysis of the erythrocytes from Case 3 suspended in a standard amount of serum complement (fresh acidified serum from the same normal subject). The amount of hemolysis in vitro was then compared to the clinical evidence for hemolysis in the patient (degree of anemia, hemoglobinemia and hemoglobinuria).

Attempts to recover a hemolytic antibody combined with the patient's cells were carried out and the following extraction methods were employed: a modification of Locke and Hirsch's method (26) of ether extraction of erythrocyte stroma ; treatment of erythrocytes with 10 per cent salt solution, using the technique of Heidelberger and Kendall (27) ; treatment with 10 per cent sucrose solution by the methods of Kosakai (28) and of Huntoon and Etris (29); extraction with 0.01 normal hydrochloric acid and sodium hydroxide; and, finally, direct use of erythrocyte stroma. Extracts of patient's or of normal red blood cells prepared by any one of the above methods were then tested for hemolytic activity with both patient's and normal cells, as described below.

In a series of preliminary experiments the efficiency of certain of these procedures was tested for recovery of the antibody from the red blood cells in 2 known antigen-antibody systems. In the first, in which sheep red blood cells were sen- sitized with antisheep cell rabbit serum, 2 extraction procedures, those of Locke and Hirsch and of Kosakai, consistently resulted in the recovery of a small fraction of the hemolytic antibody employed. Using the technique of Heidelberger and Kendall, however, none of the antibody was recovered. In the second system, in which human type I-AB cells were sensitized by the naturally occurring isohemolysins of human serum of group IV-O, none of the hemolytic antibody was recovered by the Locke-Hirsch method. It was apparent, therefore, that even with known antigen-antibody systems, only a small fraction or none of the added hemolytic antibody was recoverable by the methods here employed.

When extracts of the red blood cells of Case 3 and of a normal subject, respectively, were made by any of the above procedures, no evidence was obtained for a hemolytic substance or antibody. Stroma derived from the erythrocytes of Case 3, like that of normal cells, appeared to have no effect on normal red blood cells when suspended together in acidified serum.

\section{EXPERIMENTAL}

Sensitization of red blood cells by known hemolytic antibodies was performed as follows: Sheep cells were sensitized with 2 units of antibody by adding $200 \mathrm{cc}$. of antisheep cell rabbit serum, diluted $1: 2250$, to $6 \mathrm{cc}$. of washed packed sheep red blood cells. After incubation for 30 minutes at $37^{\circ} \mathrm{C}$. the cells were washed 3 times and then extracted by the methods mentioned above. The extracts were tested quantitatively for the amount of antibody recovered. Normal human red blood cells were sensitized by adding $17 \mathrm{cc}$. (diluted to $35 \mathrm{cc}$.) of unheated group IV-O human serum (containing a high concentration of isohemolysins) to $35 \mathrm{cc}$. of a 5 per cent suspension of washed group I-AB erythrocytes. The mixture was incubated and washed, as described above, and the sensitized erythrocytes extracted.

An ether extract of erythrocyte stroma was made of the above sensitized red cells, as well as of the red cells from Case 3 and from a normal control, employing a modification of the method described by Locke and Hirsch. From 4 to $10 \mathrm{cc}$. of the washed packed erythrocytes were treated with 2 volumes of distilled water and any unhemolyzed cells removed by centrifugation. To the supernatant liquid 7 volumes of distilled water were added, and the mixture was saturated with $\mathrm{CO}_{2}$ for 30 minutes as described by Bennett and Schmidt (30). The precipitated stroma was packed by centrifugation and then washed 4 times with distilled water, once with saline, and finally extracted 3 times with $15 \mathrm{cc}$. of ether. Three portions of the extract were tested, namely, the 
salt solution remaining after ether extraction ( 2 to 3 cc.); a saline suspension of the material containing lipoids left after evaporation of the ether; and an 0.001 normal hydrochloric acid extract of the ether-treated stroma. The action of these extracts on fresh normal and patient's cells was examined by incubating the following mixtures for 1 hour at $37^{\circ} \mathrm{C}$.: (1) Cells plus extract plus fresh acidified human serum; (2) cells plus extract; and (3) cells plus extract plus heated human serum. The supernatant fluids of mixtures (2) and (3) were then removed by centrifugation and the treated red cells tested for the presence of any "sensitization" by the addition of acidified serum in the usual manner.

Stroma from the erythrocytes of Case 3 was prepared by the method of Bennett and Schmidt and made to a 5 per cent suspension in saline. Equal quantities of suspensions of stroma and of normal erythrocyte (5 per cent) were mixed, centrifuged, and the salt removed. The cell-stroma mixtures and plain stroma were tested with acidified serum.

\section{Comparison with human isohemolysins}

In the observations reported here, the possibility is considered that the patients' red blood cells may be "sensitized" by a hemolytic antibody requiring human complement for lysis. It has been demonstrated that certain animal serums, notably guinea-pig serum, do not restore hemolytic activity to heated human serum. Since a hemolytic antibody of human origin might be concerned, and since the complement requirements were quite specific, this hemolytic system was compared to the requirements of another human hemolytic system, namely, the hemolysis of group $\mathrm{I}-\mathrm{AB}$ cells sensitized by the naturally occurring isohemolysins of serum from a normal subject of blood group IV-O.

Human cells when sensitized by human isohemolysins, as described below, were hemolyzed to the same degree as cells from Case 3 , when suspended in acidified human serum, thereby producing 2 hemolytic systems of human origin which were quantitatively comparable. Qualitatively, however, the following important differences were observed: The isohemolysin-sensitized cells were hemolyzed during incubation for 1 hour at $37^{\circ} \mathrm{C}$. with guinea-pig complement in dilutions of from $1: 10$ to $1: 40$; but unsensitized group I-AB cells or those from Case 3 were not hemolyzed under these conditions. Isohemolysinsensitized cells were significantly hemolyzed in fresh human complement when diluted 1:10 with saline or with heat-inactivated human serum, whereas the cells from Case 3 showed no hemolysis in human serum diluted $1: 2.5$. Isohemolysinsensitized erythrocytes were always hemolyzed in unaltered human serum. The degree of hemolysis however, was increased significantly by acidification of serum with hydrochloric acid. Although the cells from Case 3 required acidification for hemolysis, those of Cases 1,2 and 5 were always hemolyzed in unacidified serum (2). Acidification of serum, therefore, increased the degree of lysis for both hemolytic systems but was not necessarily an essential factor to either.

\section{EXPERIMENTAL}

Sensitization of normal human erythrocytes was affected as follows: Separate samples of $0.5 \mathrm{cc}$. of a 5 per cent suspension of washed group I-AB erythrocytes from a normal subject were mixed with $0.5 \mathrm{cc}$. samples of normal group IV-O serum, which had been heated at $56^{\circ}$ C. for 2 minutes. The mixtures were then incubated 1 hour at $37^{\circ} \mathrm{C}$. and the packed (agglutinated) cells washed once with $5 \mathrm{cc}$. of saline. These packed cells, termed isohemolysin-sensitized red cells, together with similar samples of untreated I-AB cells, and of cells from Case 3, respectively, were treated under identical conditions with group I-AB serum (as complement) acidified with hydrochloric acid, or with dilutions of unacidified guinea-pig serum. In several observations the guinea-pig serum was treated with an equal volume of packed human erythrocytes at $0^{\circ} \mathrm{C}$. for 90 minutes to reduce the natural hemolysins of guinea-pig serum for human red cells.

\section{Susceptibility of patient's erythrocytes hemolysis in 2 immunological systems}

to

In the above observations no evidence was obtained that the patient's red blood cells contained any demonstrable hemolytic substance. It was essential, however, to secure information on the behavior of patient's red blood cells when exposed to other hemolytic systems of known immunological type. Such indirect evidence might have bearing on the nature of the abnormality of the patient's erythrocytes and the type of hemolytic activity involved. The susceptibility to hemolysis of patient's and normal cells was compared, therefore, in 2 immunological hemolytic systems, one containing anti-human rabbit serum, and the other containing human isohemolysins. Complement was supplied either by human serum or guinea-pig serum. 
The anti-human rabbit serums, described in section 3, produced no greater hemolysis of the red cells from Case 3 than of those from a normal subject when guinea-pig serum was the source of complement. In the presence of human serum as complement, however, the erythrocytes of Case 3 showed a significantly greater susceptibility to hemolysis than normal cells. This was observed for the immune rabbit serums produced both by the patient's and by normal red blood cells. Under the conditions of the experiment, acidification did not increase the degree of hemolysis of patient's cells whether human or guinea-pig serum was the source of complement.

With human isohemolysins as antibody, the patient's erythrocytes were hemolyzed to a greater extent than normal erythrocytes when either human or guinea-pig serum supplied the complement.

\section{EXPERIMENTAL}

Anti-human rabbit serums were prepared as described in section 3. Serial dilutions were made of these heatinactivated serums from $1: 50$ to $1: 6400$. Human red blood cells, which were derived from Case 3 and from the same normal subject whose cells were used in producing the immune rabbit serums, were washed 3 times and made into a 5 per cent suspension. Human complement was obtained from the normal subject of blood group $\mathrm{I}-\mathrm{AB}$ and used either undiluted or diluted 1:2. Guinea-pig complement was employed as a 1:10 dilution of fresh guinea-pig serum. For acidification, 1/3 normal hydrochloric acid was added in 5 per cent by volume to the undiluted serum used as complement. Equal volumes ( 0.5 cc.) of lytic agent, complement, and cell suspension, were mixed and incubated 1 hour at $37.5^{\circ} \mathrm{C}$. and the degree of hemolysis observed. There was no hemolysis of patient's cells by the 2 lytic agents or by the 2 complements when used alone. Using anti-human rabbit serum with human complement the patient's cells were hemolyzed significantly at a dilution of $1: 3200$, the normal cells at a dilution of $1: 200$; this occurred with both the homologous and heterologous rabbit serums. Using guinea-pig complement, however, there was no significant difference in the concentration necessary for hemolysis of both cells.

Human isohemolysins were obtained from group IV-O serum. The serum was heated at $56^{\circ} \mathrm{C}$. for 2 minutes to inactivate complement and serial dilutions were made up to $1: 512$. The red cells and complement were employed as described above. Using human isohemolysins with human complement, as well as with guinea-pig complement, the patient's cells were hemolyzed significantly at a dilution of $1: 16$, the normal cells at a dilution of $1: 2$.

\section{Susceptibility of patient's erythrocytes to hemolysis in non-immunological systems}

The susceptibility to hemolysis of patient's red blood cells was investigated in certain non-immunological hemolytic systems. As reported in previous publications $(1,2,31,32)$, the susceptibility to hemolysis by hypotonic salt solutions was normal for the red blood cells of the patients studied. In the experiments reported here, the susceptibility to hemolysis of erythrocytes of Case 3 was investigated in solutions of saponin, sodium taurocholate and of cobra venom.

The susceptibility of the patient's cells to hemolysis by saponin was the same as that of normal cells and considerably less than that of cells from a patient with untreated pernicious anemia (33). In 1 observation using sodium taurocholate as lytic agent, there was no demonstrable difference in the amount of hemolysis of patient's and of normal cells. Cobra venom produced direct lysis of washed human erythrocytes without requiring a complementary substance, as shown by Kyes (24). The degree of hemolysis varied directly with the concentration of venom and depended upon whether serum or saline was employed in the mixture. The cells of Case 3 were more susceptible to hemolysis than those of the control when suspended in mixtures of serum and cobra venom; whether the serum contained active or inactivated complement appeared to exert no influence. Conversely, the cells from Case 3 were less susceptible to hemolysis than control cells in mixtures of saline and cobra venom.

\section{EXPERIMENTAL}

Saponin was employed in the time dilution method of Ponder (34) and of Ponder and Rhoads (33), and in a modification of this procedure. In the modified method, samples were prepared of $1 \mathrm{cc}$. of saponin solution diluted from $1: 1000$ to $1: 15,000$ in 1 per cent sodium chloride. Two series of such dilutions were warmed to $37.5^{\circ} \mathrm{C}$. in a water bath and to each tube was added $1 \mathrm{cc}$. of a similarly warmed 2 per cent suspension of washed red cells in 1 per cent sodium chloride. After 10 and after 40 minutes incubation the separate series were centrifuged and the amounts of hemoglobin observed in the supernatant fluids.

Sodium Taurocholate (Merck) was employed in dilutions of from $1: 1000$ to $1: 15,000$ in 1 per cent sodium chloride, as described in the above modified method. 
Cobra venom, 4 dissolved in 1 per cent sodium chloride was added to fresh human serum, serum heated 5 minutes at $56^{\circ} \mathrm{C}$., and to 1 per cent sodium chloride solutions to give concentrations of from 0.4 to $60 \mathrm{mgm}$. per $100 \mathrm{cc}$. The above preparations were mixed in equal quantities with 5 per cent suspensions of red cells from Case 3 and from a normal subject, incubated 1 hour at $37^{\circ} \mathrm{C}$. and centrifuged for comparison of hemolysis.

\section{DISCUSSION}

In previous observations (1) (2) on 5 patients with paroxysmal nocturnal hemoglobinuria, it was demonstrated that their red blood cells were hemolyzed in their own fresh serums as well as in all fresh serums from normal subjects of compatible blood groups. The patients' serums were not lytic for normal cells. The essential abnormality in this disease thus appeared to reside in the erythrocytes. The hemolytic system, however, required the presence of fresh active human serum. The treatment of such serum by certain procedures, such as heating or the addition of anticoagulants and other salts, inhibited the hemolysis of patients' cells. These procedures are all known to inactivate or inhibit serum complement. Although acidification significantly increased the degree of hemolysis, it was not necessarily an indispensable requirement of the hemolytic system. The $\mathrm{pH}$ is known to be a modifying factor of many hemolytic systems (35) and possibly of certain antigen-antibody-complement reactions. These facts suggested that an immunological reaction might constitute the basis of the hemolytic mechanism in this disease. The reaction, accordingly, was investigated for other evidences of an antigen-antibody-complement type of hemolytic system.

Since hemolysis of patients' cells occurred in all compatible fresh human serums, at least 2 possibilities were considered to explain the hemolytic mechanism : first, that the abnormal erythrocytes were hemolyzed by a substance (antibody) present in all normal serums, possibly requiring complement for lysis; and, second, that the complement itself was the serum factor required for the hemolysis of red cells which were " sensitized" by a hemolytic substance.

\footnotetext{
4 Crystalline cobra venom was obtained through the courtesy of Doctor David I. Macht of Hinson, Wescott and Dunning Co., Baltimore, Md.
}

The first possibility, that a hemolytic antibody was present in all serums, could be true only if the patients' cells were more susceptible to this antibody than normal cells. To support this hypothesis it should be possible to demonstrate certain characteristics of other human antibodies such as age distribution, specific or non-specific absorption, association with heterophile antibody, isohemolysins, isoagglutinins or cold agglutinins. In the experiments reported above, however, there was no evidence obtained to indicate the presence of such an antibody in the serums from 5 patients and from the normal subjects studied.

Consideration of the second possibility must be divided into 2 aspects : first, that complement is the serum factor required for hemolysis and, second, that the red cells are sensitized by a hemolytic substance. Concerning serum complement it was observed that all procedures which reduced, inhibited or destroyed complement or any one of the individual components of complement, also reduced or eliminated the hemolytic activity of acidified serum for patients' erythrocytes. The hemolytic activity and the complement concentration were always partially restored to inactivated human serum by the addition of fresh human serum but a relatively large volume was required for these effects.

Certain remarkable features were observed with the use of animal serums as a source of complement. The addition of large concentrations of fresh undiluted guinea-pig serum to fresh human serum usually increased its hemolytic activity for patients' erythrocytes without, however, producing hemolysis of normal cells. Similarly, guineapig serum restored in part the hemolytic activity of human serum which had been only partially inactivated by heating, to the extent that, in such heated serum, complement was definitely present but hemolytic activity was absent. Yet it is to be emphasized that neither fresh guinea-pig serum nor the serums of $\mathbf{5}$ other animals restored hemolytic activity to human serum which had been completely inactivated by heat. This is perhaps not surprising since Hegedüs and Greiner (36) have shown that the thermolabile albumin component of complement is almost or entirely lacking in serums of the rabbit, dog, pig, ox and sheep, and because Dingle et al (10) have demonstrated the failure of guinea-pig serum to activate 
certain antigen-antibody reactions. There was evidence, therefore, that the hemolytic mechanism investigated here specifically required the thermolabile components of complement derived from human serum. On the contrary, guinea-pig serum in most instances restored in part the hemolytic activity to human serums in which the thermostable components of complement were inactivated by zymin absorption or by treatment with ammonium hydroxide.

There were, however, several inconsistencies which appeared to prevent full acceptance of the identity of the serum factor essential for hemolysis to be serum complement. Three of these, i.e., increased hemolysis with acidification, failure of fresh animal serums to reactivate heated serum, and the limiting factor of dilution before complement activity was lost, have been discussed previously and may not be valid objections. Removal of hemolytic activity and complement by untreated influenza bacilli was probably due to specific anti$H$ influenza antibodies present in adult human serums (11). No explanation has been found, however, for the decrease of hemolytic activity in lyophilized serums without appreciable decrease in complement, nor for the failure to demonstrate specific utilization or fixation of complement even after hemolysis of the patient's cells had taken place repeatedly in the same serum. One explanation may lie in the extreme sensitivity of the sheep red blood cell hemolytic system to small amounts or to particular components of complement, thereby masking slight quantitative differences essential to the hemolytic mechanism in paroxysmal nocturnal hemoglobinuria. An explanation of the failure to demonstrate complement fixation may be found in the analogy that red blood cells sensitized with silicic acid, requiring complement for lysis, have very little capacity for fixing complement (37). Although serum complement cannot be identified directly, it appeared from this evidence that the serum factor in this hemolytic mechanism corresponded in its general behavior to complement or to a complement-like substance. It did not appear likely, however, that complement itself was the hemolytic agent.

The other aspect of the second possibility referred to above, namely, that patients' red blood cells might be sensitized by a hemolytic substance, was further examined. It was observed that the susceptibility to hemolysis of patients' red blood cells varied significantly from patient to patient and in the same patient. Such wide quantitative fluctuation was at least compatible with differing degrees of sensitization of red cells by a hemolytic antibody, which conceivably might result from autoimmunization. Nevertheless, no hemolytic substance associated with patients' erythrocytes could be demonstrated by a variety of procedures known to dissociate antigen-antibody combinations. It must be emphasized, however, that the methods as employed here may have been inadequate since from red blood cells sensitized to known antibodies only a small fraction or none of the absorbed antibody was recovered by certain of these extraction procedures. It was a further possibility that an abnormal constituent of the patient's red blood cells might be detectable by its antigenic properties. No antigenic difference between patient's and normal erythrocytes was demonstrable, however, when these cells were used to immunize rabbits and cross-absorption experiments were performed with the antiserums. It was observed further that the hemolytic system consisting of patient's cells and serums differed in the important feature of complement requirements from the hemolytic system consisting of human red cells sensitized with human isohemolysins and of complement derived from human or guinea pig serum. This represents indirect evidence that, if the patients' red blood cells are sensitized by an antibody, the antibody differs in behavior from human isohemolysins.

As a further immunological study, the patient's cells were subjected to hemolysis in 2 hemolytic systems known to be of the antigen-antibodycomplement type, employing as hemolytic antibodies, first, anti-human rabbit serum, and, second, the isohemolysins of human serum. In both systems, when human complement was employed, the patient's cells showed greater susceptibility to hemolysis than did normal human cells. This was suggestive but indirect evidence that the abnormality of patients' red blood cells might be related to an immunological type of reaction. Such a possibility was further emphasized by the observations that the patients' red blood cells were not abnormally susceptible to hemolysis in the nonimmunological hemolytic systems consisting of hypotonic salt solutions, saponin or sodium taurocholate. 
A third possibility which should be mentioned to explain the hemolytic system under investigation, is the hemolytic effect due to complement acting with agents other than immune bodies, as reviewed by Browning and Mackie (37). As shown by Landsteiner and co-workers $(38,39)$, red cells sensitized by colloidal silicic acid are hemolyzed in the presence of complement. By analogy it is conceivable, therefore, that in paroxysmal nocturnal hemoglobinuria the patients' red blood cells may be conditioned by a substance other than an immune body and still require serum complement for hemolysis.

From the data presented here it is apparent that the abnormality involving the red blood cells of patients with paroxysmal nocturnal hemoglobinuria can not be defined. There is a distinct possibility that these cells are sensitized by a hemolytic substance, conceivably an antibody. The origin of such a hypothetical antibody is not known but might result from autoimmunization. The serum factor essential for hemolysis is indistinguishable from serum complement. It is probable that increased acidity influences the degree of hemolysis by augmenting the activity of serum complement. The hemolytic system involved cannot be classified strictly as immunological in nature since there has been no demonstration of antigen or antibody. It is probable, however, that the hemolytic mechanism is an immunological system since complement or a complement-like substance is required for hemolysis and, presumably, because the red cells themselves show increased susceptibility to hemolysis in certain known immunological hemolytic systems.

\section{CONCLUSIONS}

1. In paroxysmal nocturnal hemoglobinuria the fundamental abnormality resided in the red blood cells which showed increased susceptibility to hemolysis when suspended in acidified plasma or serum from patients or from all normal subjects of compatible blood groups. The patients' red blood cells showed no increased susceptibility to hemolysis in the non-immunological hemolytic systems consisting of saponin, sodium taurocholate or hypotonic solutions of sodium chlorides. The patient's red blood cells showed increased susceptibility to hemolysis in the immunological hemolytic systems consisting of anti-human rabbit serum or human isohemolysins as antibody and of human serum as complement. No antigenic difference was demonstrated between patient's and normal erythrocytes when used to immunize rabbits. With the methods employed, no hemolytic substance or antibody was demonstrated when patient's cells were treated by procedures known to dissociate antibody from antigen. The abnormality of patients' red cells has not been defined.

2. No hemolytic antibody or other abnormality was demonstrated in the patients' serum when compared to normal serum. The serum factor essential for hemolysis was closely associated with, if not indistinguishable from complement or alexin of human serum. For this hemolytic system, the addition of guinea-pig serum or the serum of certain other animals did not restore the thermolabile components of human serum complement but guinea-pig serum did restore the thermostabile components.

3. The mechanism of hemolysis, probably immunological in nature, appeared to be that of an abnormal red blood cell which was hemolyzed in the presence of human complement, the degree of hemolysis varying directly with the susceptibility of the cell to lysis and with the acidity of the serum.

The authors are indebted to Miss Constance Brooks for technical assistance and to Doctors W. B. Castle, Hans Zinser and $\mathrm{K}$. Landsteiner for their suggestions in this investigation.

\section{BIBLIOGRAPHY}

1. Ham, T. H., Chronic hemolytic anemia with paroxysmal nocturnal hemoglobinuria; study of mechanism of hemolysis in relation to acid-base equilibrium. New England J. Med., 1937, 217, 915.

2. Ham, T. H., Studies on destruction of red blood cells; I. Chronic hemolytic anemia with paroxysmal nocturnal hemoglobinuria: investigation of mechanism of hemolysis with observations on five cases. Arch. Int. Med. (In press).

3. Marchiafava, E., and Nazari, A., Nuovo contributo allo studio degli itteri cronici emolitici. Policlinico (sez. med.), 1911, 18, 241.

4. Marchiafava, E., Anemia emolitica con emosiderinuria perpetua. Policlinico (sez. med.), 1931, 38, 105.

5. Micheli, F., Anemia (splenomegalia) emolitica con emoglobinuria-emosiderinuria tipo Marchiafava. Haematologica, I Arch., 1931, 12, 101.

6. Jordan, F. L. J., Etudes sur l'hemoglobinurie. Acta. Med. Scandinav., 1938, 95, 319. 
7. Osborn, T. W. B., Complement or Alexin. Oxford University Press, London, 1937.

8. Noguchi, H., Serum Diagnosis of Syphilis. Lippincott Co., Philadelphia, 1910.

9. Bing, F. C., and Baker, R. W., Determination of hemoglobin in minute amounts of blood by Wu's method. J. Biol. Chem., 1931, 92, 589.

10. Dingle, J. H., Fothergill, L. D., and Chandler, C. A., Studies on Haemophilus influenzae; failure of complement of some animal species, notably guinea pig, to activate bactericidal function of sera of certain other species. J. Immunol., 1938, 34, 357.

11. Fothergill, L. D., and Wright, J., Influenzal meningitis; relation of age incidence to bactericidal power of blood against casual organism. J. Immunol., 1933, 24, 273.

12. Ward H. K., and Enders, J. F., Analysis of opsonic and tropic action of normal and immune sera based on experiments with pneumococcus. J. Exper. Med., 1933, 57, 527.

13. Dacie, J. V., Israels, M. C. G., and Wilkinson, J. F., Paroxysmal nocturnal haemoglobinuria of the Marchiafava type. Lancet, 1938, 1, 479.

14. Thannhauser, S. J., and Setz, P., Studies on animal lipids; method for quantitative determination of diaminophosphatide in organs and fluids; application to stromata of red blood cells and serum. J. Biol. Chem., 1936, 116, 533.

15. Van den Bergh, A. A. H., Ictere hemolytique avec crises hemoglobinuriques. Fragilite globulaire. Revue de Med., 1911, 31, 63.

16. Flosdorf, E. W., and Mudd, S., Procedure and apparatus for preservation in "lyophile" form of serum and other biological substances. J. Immunol., 1935, 29, 389.

17. Strong, P. S., and Culbertson, J. T., Filtrability of components of alexin. J. Hyg., 1934, 34, 522.

18. Wright, H. D., and MacCallum, P., Effect of electrolytes on hemolysis. J. Path. and Bacteriol., 1922, 25, 316.

19. Wadsworth, A., Maltaner, F., and Maltaner, E., Studies on activity of cephalin as it relates to coagulative and complementary properties of blood. J. Immunol,, 1936, 30, 417.

20. Wadsworth, A., Maltaner, F., and Maltaner, E., Inhibition of complementary activity by anticoagulants. J. Immunol., 1937, 33, 297.

21. Liefmann, H., Ueber den Mechanismus der Seroreaktion der Lues. München. med. Wchnschr., 1909, 56, 2097.

22. Whitehead, H. R., Gordon, J., and Wormall, A., The "third component" or heat-stable factor of complement. Biochem. J., 1925, 19, 618.
23. Gordon, J. E., Whitehead, H. R., and Wormall, A., Action of ammonia on complement; fourth component. Biochem. J., 1926, 20, 1028.

24. Kyes, P., Venom hemolysis. J. Infect. Dis., 1910, $7,181$.

25. Browning, C. H., and Mackie, T. J., Relationship of complementing action of fresh serum along with immune body to its haemolytic effect with cobra venom; contribution on structure of complement. Zeitsch. f. Immuntätsforsch., 1913, 17, 1.

26. Locke, A., and Hirsch, E. F., Isolation of substances with immune properties. J. Infect. Dis., 1925, 37, 449.

27. Heidelberger, M., and Kendall, F. E., Quantitative studies on antibody purification; dissociation of precipitates formed by pneumococcus specific polysaccharides and homologous antibodies. J. Exper. Med., 1936, 64, 161.

28. Kosakai, M., Isolation, purification and concentration of immune bodies: study of immune hemolysin. J. Immunol., 1918, 3, 109.

29. Huntoon, F. M., and Etris, S., Antibody studies; recovery of antibody from sensitized antigens: technic. J. Immunol., 1921, 6, 123.

30. Bennett, C. B., and Schmidt, C. L. A., On red cell globulin. J. Immunol., 1919, 4, 29.

31. Witts, L. J., Paroxysmal haemoglobinurias. Lancet, 1936, 2, 115.

32. Hamburger, L. P., and Bernstein, A., Chronic hemolytic anemia with paroxysmal nocturnal hemoglobinuria. Am. J. M. Sc., 1936, 192, 301.

33. Ponder, E., and Rhoads, C. P., Red cell resistance to lysins in pernicious anemia. Proc. Soc. Exp. Biol. and Med., 1938, 38, 540.

34. Ponder, E., Protoplasma. Monographien. The Mammalian Red Cell and the Properties of Haemolytic Systems. Verlag. von Gebrüder Borntraeger, Berlin, 1934.

35. Walbum, L. E., Importance of hydrogen ion concentration in hemolysis by lysins of anaerobic bacteria. J. Path., and Bact., 1938, 46, 85.

36. Hegedüs, A., and Greiner, H., Quantitative Bestimmung der Komplementbestandteile. Ztschr. f. Immunitätsforsch. u. exper. Therap., 1938, 92, 1.

37. Browning, C. H., and Mackie, T. J., Immunochemical Studies. Constable and Co., London, 1925.

38. Landsteiner, $\mathrm{K}$, und Jagic, N., Ueber Reaktionen anorganischer Kolloide und Immunkörperreaktionen. München. med. Wchnschr., 1904, 51, 1185.

39. Landsteiner, $K$., and Rock, $H$., Untersuchungen über Komplementwirkung. Hämolyse durch Kieselsäure und Komplement. Ztschr. f. Immunitätsforsch., 1912, 14, 14. 